\title{
The effect of administration of silver nanoparticles on silver accumulation in tissues and immune and antioxidant status of chickens
}

\author{
E. Kulak, K. Ognik' ${ }^{1}$ A. Stępniowska and I. Sembratowicz \\ University of Life Sciences in Lublin, Faculty of Biology, Animal Sciences and Bioeconomy, \\ Department of Biochemistry and Toxicology, Akademicka 13, 20-950 Lublin, Poland
}

KEY WORDS: nanosilver, chickens, tissues, accumulation, redox status

Received: $\quad 5$ October 2017

Revised: 24 November 2017

Accepted: 26 February 2018

${ }^{1}$ Corresponding author:

e-mail: kasiaognik@poczta.fm

\begin{abstract}
The aim of the study was to determine whether silver nanoparticles (Ag-NPs) administered per os to chickens as a hydrocolloid at a dose of 2.87 or $12.25 \mathrm{mg}$ per bird per whole experiment (D1 and D2, respectively) will affect the accumulation of this element in tissues, immune and antioxidant responses, and how the increasing of the Ag-NPs size from $5 \mathrm{~nm}$ to 25 or $40 \mathrm{~nm}$ (S-5, S-25 and S-40, respectively) will influence these processes. The experiment was carried out on 280 chickens assigned to 7 experimental groups. The control group did not receive Ag-NPs. Other chickens received a hydrocolloid of Ag-NPs at a concentration of $5 \mathrm{mg} \cdot \mathrm{I}^{-1}$ in the drinking water in 1 cycle $\times 7$ days (days 8-14 of life) for D1 and in 2 cycles $\times 7$ days (days 8-14 and 36-42 of life) for D2. Neither Ag-NPs addition influences performance parameters of birds. All sizes of Ag-NPs were accumulated in the intestine and liver with the higher dose the higher accumulation relation. The villus height to crypt depth ratio in jejunum was decreased by Ag-NPs administration. All doses and sizes of Ag-NPs stimulated the immune system (except S-40 $0_{(\mathrm{D} 1)}$ treatment) and intensified oxidation stress in relation to the control group. However, the changes observed in the immunological indices do not allow to draw clear conclusions about the occurrence of inflammation state in the organism of chickens receiving Ag-NPs. Concluding, it has been demonstrated that oral administration of $\mathrm{Ag}-\mathrm{NPs}$ to chickens influences the morphology of the gastrointestinal tract and the parameters of immune and redox status. This effect varies depending on the dose and size of used Ag-NPs, so there is still a need for further investigation in order to assess the suitability of Ag-NPs in poultry nutrition.
\end{abstract}

\section{Introduction}

Silver is an antibiotic with unique properties on the nanoscale that has been used in many fields (McShan et al., 2014). Silver nanoparticles (Ag-NPs), due to their antibacterial properties, are used in animal production as disinfectants and in order to reduce emissions of ammonia and nitrogen oxides (Xu et al., 2013). Currently, studies on their use in poultry diets are conducted (e.g., Ognik et al., 2016a,b).

Apart from advantages, the use of nanometals entails the risk of their accumulation in the body. According to Panyala et al. (2008), only $10-20 \%$ of metallic silver is absorbed in the gastrointestinal tract, primarily in the duodenum and small intestine. However, when van der Zande et al. (2012) administered nanosilver (15 and $20 \mathrm{~nm}$ ) to rats for 
28 days, a high content of this metal in the walls of the stomach and small and large intestines was found. The toxicity of absorbed nanosilver depends on many factors, mainly on the surface oxidation of nanoparticles, the release of $\mathrm{Ag}^{+}$ions, and thus interactions with biomolecules (Reidy et al., 2013). Accumulation of nanosilver in the cytoplasm can impair mitochondrial function through mechanical damage or by blocking electron transport in the respiratory chain, resulting in increased reactive oxygen species (ROS) production (AshaRani et al., 2009). In addition, silver ions can replace iron in proteins and induce a Fenton reaction, which leads to generation of ROS (Gordon et al., 2010). Due to the high affinity for sulphur groups, silver binds to glutathione (GSH) in cells, impairing its antioxidant functioning and thereby increasing cell susceptibility to ROS (Carlson et al., 2008). ROS resulting from the action of nanosilver can arrest cell division and cause death via cell membrane lipid peroxidation, activation of the caspase cascade, impairment of autophagocytosis, and damage to DNA and RNA (Wang et al., 2015). There is, however contradictory information regarding the effects of metallic nanoparticles, including nanosilver, on immune processes (Wen et al., 2016). As yet, not cytotoxic but only immunosuppressive effect on immunocompetent cells has been demonstrated. In a number of studies a stimulating effect of metal nanoparticles on the activity of phagocytic cells - macrophages, dendritic cells and peripheral blood phagocytes was indicated (Małaczewska, 2014). These cells easily ingest nanoparticles, which can lead to the expression of proinflammatory cytokines such as tumour necrosis factor (TNF)-alpha, interleukin 1 (IL-1) and interleukin 6 (IL-6) (Yen et al., 2009).

It was assumed that the size of Ag-NPs in a hydrocolloid and the dose of Ag-NPs applied per os to chickens affect $\mathrm{Ag}$ accumulation in tissues and the body immune and antioxidant responses. The aim of the study was to determine how increasing the size of Ag-NPs from $5 \mathrm{~nm}$ to 25 or $40 \mathrm{~nm}$ in a hydrocolloid administered to chickens at a dose of 2.87 or $12.25 \mathrm{mg}$ per bird will affect the accumulation of this element in the tissues and the immune and antioxidant responses.

\section{Material and methods}

\section{Nanoparticles}

In the study an aqueous solution of a silver nanocolloid at a concentration of $50 \mathrm{mg} \cdot 1^{-1}$ was used (the one concentration for Ag-NPs size 5, 25 and $40 \mathrm{~nm}$ ). Concentrations of $5 \mathrm{mg} \cdot \mathrm{l}^{-1}$ were taken from this solution to perform the experiment. Ag-NPs were non- ionic, nanocrystalline, chemically pure and were produced in a physical process (a non-explosive, high-current method for degradation of metals) by a patented technology licensed by Nano Technologies Group, Inc. (Chicago, IL, USA). All information about this product are included in European Patent Specification (EP 2081672 B1). Figure 1 presents magnified crystalline metallic nano-particles (nano-crystallites) using transmission electron microscopy (TEM). The silver platelets are so thin, that the graphite substrate of the carbon substrate membrane is 'visible' through them (Figure 1).

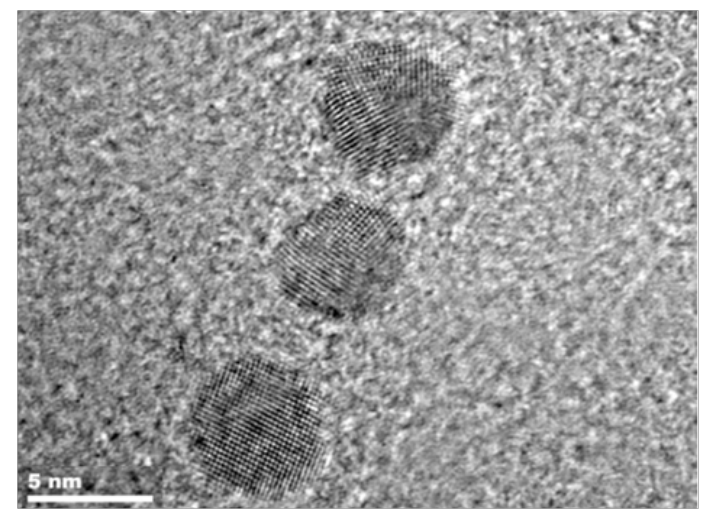

Figure 1. Transmission electron microscopy (TEM) images of pure silver particles (Kulak et al., 2018a)

On the basis of photographs taken by a transmission electron microscopes Tecnai G2 T20 X-TWIN (FEI, Hillsboro, OR, USA) and LEO 912AB (Carl Zeiss $\mathrm{GmbH}$, Jena, Germany), the average size of the Ag-NPs was estimated at about $5 \mathrm{~nm}$ (Figure 2).

\section{Animals}

The study was conducted on 1-day-old Ross 308 male chickens raised until the age of 42 days. The experimental procedure was approved by the Second Local Ethics Committee for Experiments with Animals in Lublin (approval no. 30/2014). The birds were kept in pens on straw litter and reared in standard conditions in a building with regulated temperature and humidity. Animals had ad libitum access to drinking water and complete compound feeds (Table 1). The nutritional value of feeds corresponded to the value of feeds used in practical feeding of broiler chickens in Poland. The nutritional value of the basal diets was calculated according to the Polish Feedstuff Analysis Tables (Smulikowska and Rutkowski, 2005). The experiment was carried out on 280 chickens assigned to 7 experimental groups of 40 birds each (4 replications of 10 individuals each). 

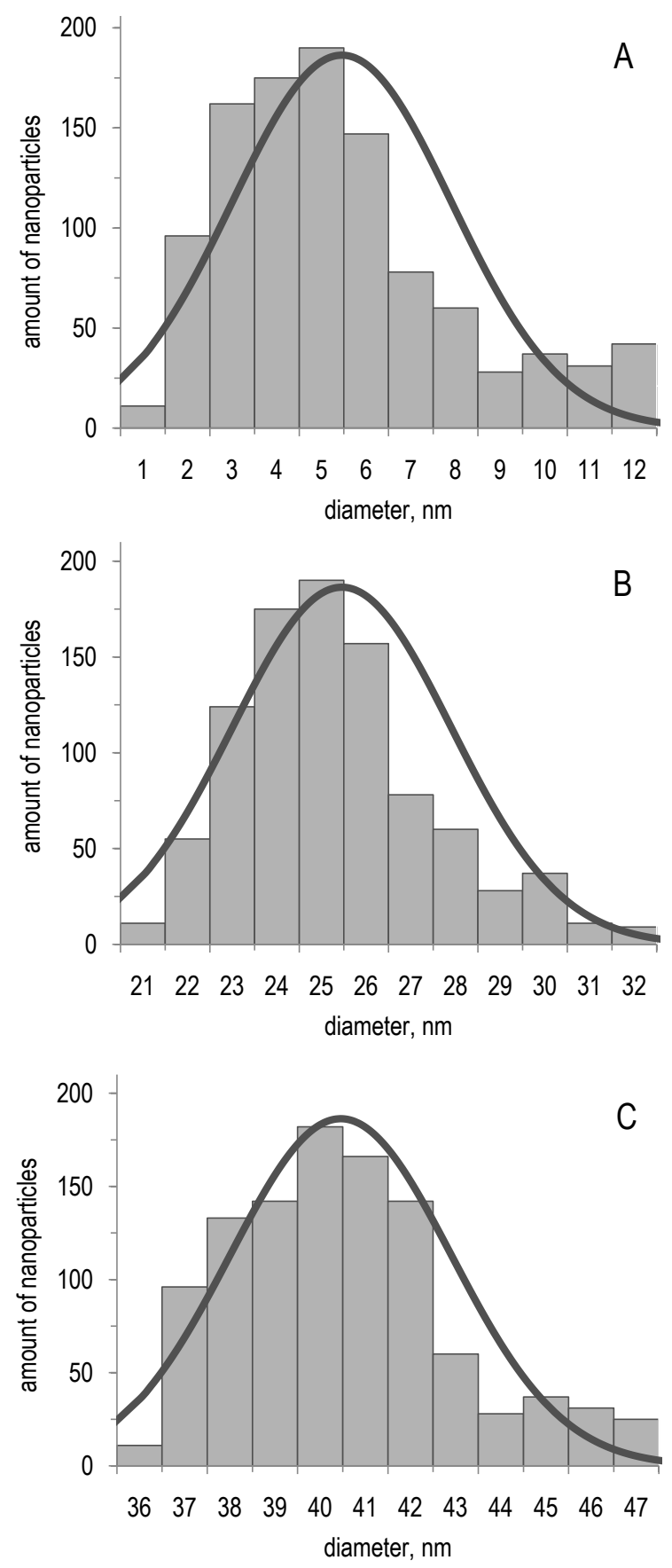

Figure 2. Hydrocolloid of silver nanoparticles (Ag-NPs) size distribution: A $-5 \mathrm{~nm}, \mathrm{~B}-25 \mathrm{~nm}$ and $\mathrm{C}-40 \mathrm{~nm}$

The control (C) group did not receive Ag-NPs (Table 2). The chickens in groups $\mathrm{S}-5_{(\mathrm{D} 1)}, \mathrm{S}-5_{(\mathrm{D} 2)}$ $\mathrm{S}-25_{(\mathrm{D} 1)}, \mathrm{S}-25_{(\mathrm{D} 2)}, \mathrm{S}-40_{(\mathrm{D} 1)}$ and $\mathrm{S}-40_{(\mathrm{D} 2)}$ received a hydrocolloid of Ag-NPs at a concentration of 5 $\mathrm{mg} \cdot \mathrm{1}^{-1}$ as a drinking water (Table 2 ). The chickens in groups $\mathrm{S}-5_{(\mathrm{D} 1}$ and $\mathrm{S}-5_{(\mathrm{D} 2)}$ received Ag-NPs $5 \mathrm{~nm}$ in size, groups $\mathrm{S}-25_{(\mathrm{D} 1)}$ and $\mathrm{S}-25_{(\mathrm{D} 2)}$ received $25 \mathrm{~nm} \mathrm{Ag}$ $\mathrm{NPs}$, and groups $\mathrm{S}-40_{(\mathrm{D} 1)}$ and $\mathrm{S}-40_{(\mathrm{D} 2)}$ were given $40 \mathrm{~nm}$ Ag-NPs. The chickens received the hydrocolloid of Ag-NPs at a dosage of $2.87 \mathrm{mg}$ per bird per whole experiment $(1$ cycle $\times 7$ days; days $8-14$ of life $)-$
Table 1. Composition of diets for broiler chickens

\begin{tabular}{|c|c|c|c|}
\hline Indices & $\begin{array}{l}\text { Starter } \\
\text { weeks } \\
1-3\end{array}$ & $\begin{array}{l}\text { Grower } \\
\text { weeks } \\
4-5\end{array}$ & $\begin{array}{l}\text { Finisher } \\
\text { week } \\
6\end{array}$ \\
\hline \multicolumn{4}{|l|}{ Ingredients, $\mathrm{g} \cdot \mathrm{kg}^{-1}$} \\
\hline wheat & 452.8 & 367.6 & 330.7 \\
\hline maize & 150.0 & 250.0 & 300.0 \\
\hline soyabean meal & 272.2 & 227.9 & 178.1 \\
\hline rapeseed meal & 20.0 & 40.0 & 60.0 \\
\hline soyabean oil & 20.0 & 40.0 & 60.0 \\
\hline $\mathrm{DDGS}^{1}$ & 40.07 & 43.58 & 46.87 \\
\hline monocalcium phosphate & 11.03 & 5.42 & 2.05 \\
\hline $\mathrm{CaCO}_{3}$ & 16.07 & 10.93 & 8.52 \\
\hline $\mathrm{NaCl}$ & 3.63 & 3.23 & 2.83 \\
\hline DL-methionine (99\%) & 3.61 & 2.40 & 2.00 \\
\hline L-lysine $\mathrm{HCl}(78 \%)$ & 4.27 & 2.97 & 3.12 \\
\hline L-threonine (99\%) & 1.31 & 0.94 & 0.82 \\
\hline Premix $x^{2,3}$ & 5.0 & 5.0 & 5.0 \\
\hline \multicolumn{4}{|l|}{ Calculated composition, $\mathrm{g} \cdot \mathrm{kg}^{-1}$} \\
\hline $\begin{array}{l}\text { metabolisable energy, } \\
\mathrm{kcal} \cdot \mathrm{kg}^{-1}\end{array}$ & 3070 & 3140 & 3190 \\
\hline crude protein & 210.0 & 198.5 & 187.5 \\
\hline crude fibre & 27.2 & 29.8 & 32.2 \\
\hline crude fat & 65.9 & 74.5 & 81.4 \\
\hline Lys & 13.5 & 11.7 & 10.9 \\
\hline Met & 6.7 & 5.5 & 5.0 \\
\hline Met + Cys & 10.1 & 8.8 & 8.3 \\
\hline Trp & 2.5 & 2.3 & 2.1 \\
\hline $\operatorname{Arg}$ & 13.1 & 12.1 & 11.1 \\
\hline $\mathrm{Ca}$ & 9.8 & 7.3 & 6.0 \\
\hline P available & 3.9 & 2.8 & 2.1 \\
\hline $\mathrm{Na}$ & 1.6 & 1.5 & 1.4 \\
\hline
\end{tabular}

${ }^{1}$ DDGS - maize distillers dried grains with solubles; ${ }^{2}$ vitamin provided per kg of diet: wks 1-3: IU: vit. A 15000 , vit. $D_{3} 5000$, vit. E 112; mg: vit. $K_{3} 4$, vit. $B_{1} 3$, vit. $B_{2} 8$, vit. $B_{6} 5$, vit. $B_{12} 16$, folic acid 2 , biotin 0.2 , nicotinic amid 60 , calcium pantothenicum 18; g: choline 1.8; wks 4-5: IU: vit. $A 12000$, vit. $D_{3} 5000$, vit. $E 75$; mg: vit. $K_{3} 2$, vit. $B_{1} 2$, vit. $B_{2} 6$, vit. $B_{6} 4$, vit. $B_{12} 16$, folic acid 1.75 , biotin 0.05 , nicotinic amid 60 , calcium pantothenicum 18; g: choline 1.6; wk 6: IU: vit. A 12 000, vit. $D_{3} 5000$, vit. $E 75$; mg: vit. $K_{3} 2$, vit. $B_{1} 2$, vit. $B_{2} 5$, vit. $B_{6} 3$, vit. $B_{12} 11$, folic acid 1.5 , biotin 0.05 , nicotinic amid 35 , calcium pantothenicum 18; g: choline 1.6; ${ }^{3}$ trace minerals provided per $\mathrm{kg}$ of diet: mg: Mn 100, Zn 80, Fe 80, Cu 8, I 1, Se 0.15; coccidiostat salinomycin (except wk 6)

groups $\mathrm{S}-5_{(\mathrm{D} 1)}, \mathrm{S}-25_{(\mathrm{D} 1)}$ and $\mathrm{S}-40_{(\mathrm{D} 1)}$, and at a dosage of $12.25 \mathrm{mg}$ per bird per whole experiment (in 2 cycles $\times 7$ days; days $8-14$ and 36-42 of life) groups $\mathrm{S}-5_{(\mathrm{D} 2)}, \mathrm{S}-25_{(\mathrm{D} 2)}$ and $\mathrm{S}-40_{(\mathrm{D} 2)}$. The periods of administration of Ag-NPs were based on the results of our previous research (Kulak et al., 2018a,b). In those studies it was found that administration of AgNPs in doses of 2.87-12.25 mg per bird stimulated immune and antioxidant status without inducing an inflammatory reaction or oxidative stress and with no negative effect on meat quality (Kulak et al., 
Table 2. Experimental design

\begin{tabular}{|c|c|c|c|c|c|c|c|}
\hline \multirow[b]{2}{*}{ Indices } & \multicolumn{7}{|c|}{ Treatment $^{1}$} \\
\hline & $\bar{C}$ & $\mathrm{~S}-5_{(\mathrm{D} 1)}$ & $\mathrm{S}-5_{(\mathrm{D} 2)}$ & $\mathrm{S}-25_{(\mathrm{D}}$ & $\mathrm{S}-25_{(\mathrm{D} 2}$ & ${ }_{22} \mathrm{~S}-40_{(\mathrm{D} 1)}$ & $\mathrm{S}-40_{(\mathrm{D} 2}$ \\
\hline Size of Ag-NPs, nm & 0 & 5 & 5 & 25 & 25 & 40 & 40 \\
\hline $\begin{array}{l}\text { Concentration } \\
\text { of Ag-NPs, } \mathrm{mg} \cdot \mathrm{I}^{-1}\end{array}$ & 0 & 5 & 5 & 5 & 5 & 5 & 5 \\
\hline $\begin{array}{l}\text { Cyclical } \\
\text { administration } \\
\text { of }{\mathrm{Ag}-\mathrm{NPs}^{2}}^{2}\end{array}$ & 0 & $1 \times 7$ & $2 \times 7$ & $1 \times 7$ & $2 \times 7$ & $1 \times 7$ & $2 \times 7$ \\
\hline $\begin{array}{l}\text { Total Ag-NPs } \\
\text { applied, mg } \cdot \text { bird }^{-1}\end{array}$ & 0 & 2.87 & 12.25 & 2.87 & 12.25 & 2.87 & 12.25 \\
\hline
\end{tabular}

${ }^{1} \mathrm{C}$ - control group which did not receive silver nanoparticles (Ag-NPs), S-5, S-25 and S-40 - groups in which chickens received 5, 25 and 40-nm Ag-NPs, respectively; D1 and D2 - groups in which Ag-NPs were administrated at a dose of 2.87 and $12.25 \mathrm{mg}$ per bird per whole experiment, respectively; ${ }^{2} 1 \times 7$-administration on days 8-14 of life, or $2 \times 7$-administration on days 8-14 and 36-42 of life

2018b). At 42 day of age, blood samples were collected from 2 birds per replicate $(8$ birds per group) representing average body weight (BW); after slaughter, the liver, heart, small intestinal wall, jejunum and breast muscle were collected for histological and biochemical analyses.

\section{Laboratory analysis}

The leukocyte count (WBC) in the blood was estimated in an Abacus Junior Vet haematology analyser (Diatron, Budapest, Hungary). The Wintrobe method was used to determine the erythrocyte sedimentation rate (ESR) in the blood, i.e. the rate at which erythrocytes settle out of unclotted blood in $1 \mathrm{~h}$ (Bomski, 1995). Ceruloplasmin (Cp) activity in the blood plasma was determined by the $p$-phenylenediamine colorimetric method according to Sunderman and Nomoto (1970). The immunological analyses involved determination of the phagocytic activity of leukocytes against the Staphylococcus aureus 209P strain, expressed as the percentage of phagocytic cells (\% PC) and the phagocytic index (PI) (Siwicki et al., 1994). The respiratory burst activity of the heterophils was quantified by nitroblue tetrazolium reduction (NBT) to formazan as a measurement of production of oxygen radicals (Park et al., 1968). The concentration of immunoglobulins (Ig) A and Y, and IL-6 in the blood were determined using assays from Elabscience Biotechnology Co., Ltd (Houston, TX, USA). Serum lysozyme content was determined by the turbidimetric method (Siwicki and Anderson, 1993). Superoxide dismutase (SOD) and glutathione peroxidase (GPx) activity in the erythrocytes was determined using Ransod and Ransel diagnostics kits from Randox
(Belfast, North Ireland), and catalase activity (CAT) was determined according to Aebi (1984). Plasma content of reduced and oxidized form of glutathione (GSH and GSSG, respectively), lipid peroxides (LOOH) and malondialdehyde (MDA) were determined according to methods described by Ognik and Wertelecki (2012).

Silver contents in samples of the liver, heart, small intestinal wall and breast muscle were determined by inductively coupled plasma optical emission spectrometry (ICP-OES). The following indicators of antioxidant status were determined in the breast muscle as described previously (Ognik and Wertelecki, 2012): SOD and CAT activity and concentration of LOOH, MDA, GSH and GSSG.

Samples of the intestine (jejunum) were cut in two lengthwise and fixed for $24 \mathrm{~h}$ in $5 \%$ formalin, $\mathrm{pH}$ 7.2. Within $24 \mathrm{~h}$ the fixed tissue fragments were passed through increasing concentrations of alcohol solutions, acetone and xylene into paraffin blocks in a tissue processor (Leica TP-20, Leica, Nussloch, Germany). Paraffin-embedded microscope sections $5 \mu \mathrm{m}$ thick were stained with haematoxylin and eosin (HE staining). Morphometric evaluation of the length of the villi and depth of the crypts was carried out using a computer-assisted microscopic image analysis system. The system includes a light microscope (Nikon Eclipse E600, Nikon INC., Melville, NY, USA) with a digital camera (Nikon DSFil, Nikon INC., Melville, NY, USA) and a computer with image-analysis software (NIS-Elements BR-2.20, Laboratory Imaging, Nikon INC., Melville, NY, USA). In each jejunum tissue slide 20 villi cut in two lengthwise and 20 crypts were measured. The length of the villus was measured from the tip to the base.

\section{Statistical analysis}

The model assumptions of normality and homogeneity of variance were examined by the Shapiro-Wilk and Levene tests, respectively. The comparison of control group vs all other groups was performed by planned contrast analysis. In a model without the control (C), two-way ANOVA was performed to examine main effects: $\mathrm{S}$ - Ag-NP size effect $(5,25$ and $40 \mathrm{~nm}), \mathrm{D}$ - dosage effect $(2.87 \mathrm{mg}$ and $12.25 \mathrm{mg}$ per bird per whole experiment, D1 and $\mathrm{D} 2$, respectively), and the interaction between these two factors $(\mathrm{S} \times \mathrm{D})$ ). If the analysis revealed a significant interaction $(P \leq 0.05)$, the differences between treatment groups $\left(\mathrm{S}-5_{(\mathrm{D})}, \mathrm{S}-5_{(\mathrm{D} 2)}, \mathrm{S}-25_{(\mathrm{D} 1)}\right.$, $\mathrm{S}-25_{(\mathrm{D} 2)}, \mathrm{S}-40_{(\mathrm{D} 1)}$ and $\left.\mathrm{S}-40_{(\mathrm{D} 2)}\right)$ were then determined by the Newman-Keuls post hoc test at $P \leq 0.05$. 
The statistical analysis was performed according to the GLM procedure for Statistica 8.0 PL software (StatSoft Polska, Krakow, Poland). Treatment effects were considered to be significant at $P \leq 0.05$. All data were expressed as mean values with pooled standard error (SE).

\section{Results}

\section{Effect of addition of silver nanoparticles}

It was found that the application of Ag-NPs had no adverse effect on the chicken growth performance (Table 3). The survival rate of the chickens was $100 \%$. Per os administration of a hydrocolloid of Ag-NPs resulted in the accumulation of this element in the small intestine and liver (both $P<0.001$ ), but not in the heart or breast muscle. Accumulation

Table 3. Performance parameters of chickens

\begin{tabular}{|c|c|c|c|}
\hline \multicolumn{2}{|l|}{ Indices } & $\begin{array}{l}\text { Body weight, } \\
\mathrm{kg} \cdot \text { bird }^{-1} \\
1-42 \text { day }\end{array}$ & $\begin{array}{l}\text { Feed conversion } \\
\text { ratio, } \mathrm{kg} \cdot \mathrm{kg}^{-1} \\
1-42 \text { day }\end{array}$ \\
\hline \multicolumn{4}{|l|}{ Treatment $^{1}$} \\
\hline control & & 2.260 & 1.69 \\
\hline \multicolumn{4}{|l|}{ Ag-NP-treated } \\
\hline$S-5_{(D 1)}$ & & 2.250 & 1.68 \\
\hline$S-5_{(D 2)}$ & & 2.245 & 1.68 \\
\hline$S-25_{(D 1)}$ & & 2.265 & 1.70 \\
\hline S-25(D2) & & 2.248 & 1.71 \\
\hline$S-40_{(D 1)}$ & & 2.250 & 1.69 \\
\hline$S-40_{(02)}$ & & 2.265 & 1.70 \\
\hline SEM & & 0.043 & 0.012 \\
\hline \multicolumn{4}{|l|}{ Main effects } \\
\hline \multirow[t]{3}{*}{ size effect (S) } & S-5 & 2.247 & 1.68 \\
\hline & S-25 & 2.256 & 1.70 \\
\hline & S-40 & 2.257 & 1.69 \\
\hline \multirow[t]{2}{*}{ dosage effect (D) } & $\mathrm{D} 1$ & 2.255 & 1.69 \\
\hline & $\mathrm{D} 2$ & 2.252 & 1.68 \\
\hline \multicolumn{4}{|l|}{$P$-value } \\
\hline \multicolumn{2}{|l|}{ control vs all others } & 0.158 & 0.695 \\
\hline \multicolumn{2}{|l|}{ S effect } & 0.263 & 0.963 \\
\hline \multicolumn{2}{|l|}{ D effect } & 0.642 & 0.884 \\
\hline \multicolumn{2}{|l|}{$S \times D$ interaction } & 0.084 & 0.692 \\
\hline
\end{tabular}

${ }^{1}$ see Table 2; SEM - standard error of the mean (SD for all chickens divided by square root of number of chickens, $n=56$ )

of larger Ag nanoparticles was greater in the intestines than in the liver (Table 4). As compared to the control, the intestinal villi were longer in chickens from the $\mathrm{S}-5_{(\mathrm{D} 1)}$ treatment, but shorter in chickens from S-25 ${ }_{(\mathrm{D} 1)}, \mathrm{S}-25_{(\mathrm{D} 2)}, \mathrm{S}-40_{(\mathrm{D} 1)}$ and $\mathrm{S}-40_{(\mathrm{D} 2)}$ treatments $(P=0.006)$. At the same time, crypt depth
Table 4. Content of Ag in intestine, liver, heart and breast muscle of chickens

\begin{tabular}{|c|c|c|c|c|c|}
\hline \multirow{2}{*}{ Indices } & & \multicolumn{4}{|c|}{ Content of $\mathrm{Ag}, \mathrm{ng} \cdot \mathrm{g}^{-1}$} \\
\hline & & \multirow[t]{2}{*}{ Intestine } & \multirow[t]{2}{*}{ liver } & \multirow[t]{2}{*}{ heart } & $\begin{array}{l}\text { breast } \\
\text { muscle }\end{array}$ \\
\hline \multicolumn{3}{|l|}{ Treatment $^{1}$} & & & \\
\hline control & & $<\mathrm{LOQ}$ & $<L O Q$ & $<L O Q$ & $<L O Q$ \\
\hline \multicolumn{6}{|l|}{ Ag-NP-treated } \\
\hline$S-5_{(D 1)}$ & & $0.340^{\mathrm{e} *}$ & $0.375^{\mathrm{b*}}$ & $<L O Q$ & $<\mathrm{LOQ}$ \\
\hline$S-5_{(D 2)}$ & & $0.898^{\mathrm{b*}}$ & $0.482^{\mathrm{a}^{*}}$ & 0.02 & $<\mathrm{LOQ}$ \\
\hline$S-25_{(D 1)}$ & & $0.426^{\mathrm{d} *}$ & $0.168^{\mathrm{d} *}$ & $<L O Q$ & $<L O Q$ \\
\hline $\mathrm{S}-25_{(\mathrm{D} 2)}$ & & $1.030^{\mathrm{ab} *}$ & $0.232^{c *}$ & $<L O Q$ & $<\mathrm{LOQ}$ \\
\hline$S-40_{(D 1)}$ & & $0.595^{c *}$ & $0.105^{e^{*}}$ & $<L O Q$ & $<\mathrm{LOQ}$ \\
\hline $\mathrm{S}-40_{(\mathrm{D} 2)}$ & & $1.230^{\mathrm{a} *}$ & $0.158^{\mathrm{d} *}$ & $<L O Q$ & $<L O Q$ \\
\hline SEM & & 0.033 & 0.012 & - & - \\
\hline \multicolumn{6}{|l|}{ Main effects } \\
\hline \multirow[t]{3}{*}{ size effect (S) } & S-5 & $0.619^{c}$ & $0.428^{\mathrm{a}}$ & - & - \\
\hline & S-25 & $0.728^{b}$ & $0.200^{\mathrm{b}}$ & - & - \\
\hline & S-40 & $0.912^{\mathrm{a}}$ & $0.131^{c}$ & - & - \\
\hline \multirow[t]{2}{*}{ dosage effect (D) } & $\mathrm{D} 1$ & $0.453^{B}$ & $0.216^{B}$ & - & - \\
\hline & $\mathrm{D} 2$ & $1.052^{\mathrm{A}}$ & $0.290^{A}$ & - & - \\
\hline \multicolumn{6}{|l|}{$P$-value } \\
\hline \multicolumn{2}{|c|}{ control vs all others } & $<0.001$ & $<0.001$ & & \\
\hline \multicolumn{2}{|l|}{ S effect } & 0.014 & 0.001 & - & - \\
\hline \multicolumn{2}{|l|}{ D effect } & 0.002 & 0.016 & - & - \\
\hline \multicolumn{2}{|l|}{$S \times D$ interaction } & 0.036 & 0.042 & - & - \\
\hline
\end{tabular}

${ }^{1}$ see Table $2 ;<\mathrm{LOQ}$ - limit of quantification $(0.001) ;{ }^{*}-$ means within the same column differ significantly from the control at $P \leq 0.05$ as a result of Dunnett's mean comparison; ${ }^{\mathrm{a}-\mathrm{e}}$ or ${ }^{\mathrm{A}-\mathrm{B}}$ - means within the same column with different superscripts differ significantly $(P \leq 0.05)$ according to Newman-Keuls test (for treatments only if interaction $S \times T$ is significant; for main effects only if main effect $(S$ or $D)$ is significant); SEM - standard error of the mean (SD for all chickens divided by square root of number of chickens, $n=56$ )

was found to be greater $(P=0.012)$ in chickens from $\mathrm{S}-25_{(\mathrm{D} 1)}, \mathrm{S}-25_{(\mathrm{D} 2)}, \mathrm{S}-40_{(\mathrm{D} 1)}$ and $\mathrm{S}-40_{(\mathrm{D} 2)}$ treatments than in the control (Table 5). Blood analysis revealed that the administration of the Ag-NPs hydrocolloid resulted in an increase in ESR in chickens from the $\mathrm{S}-40_{(\mathrm{D} 2)}$ treatments $(P=0.024)$, an increase in IL-6 content in chickens from S-5 $5_{(\mathrm{D} 1)}, \mathrm{S}-25_{(\mathrm{D} 1)}$ and $\mathrm{S}-40_{(\mathrm{D} 2)}$ treatment $(P=0.048)$, and a decrease in Cp activity $(P=0.039)$ in chickens from $\mathrm{S}-5_{(\mathrm{D} 1)}$ and S-5 (D2) treatments, with respect to the control (Table 6). The blood of chickens from S-5 (D2), $\mathrm{S}-25_{(\mathrm{D} 2)}$ and $\mathrm{S}-40_{(\mathrm{D} 2)}$ treatments was characterized by a higher NBT value than that of the control chickens $(P=0.042)$. Higher lysozyme content $(P=0.039)$ was noted in the blood of chickens from S-5 $(\mathrm{D} 1)$, $\mathrm{S}-5_{(\mathrm{D} 2)}, \mathrm{S}-25_{(\mathrm{D} 1)}$ and $\mathrm{S}-40_{(\mathrm{D} 2)}$ treatments than in the control (Table 7). In chickens administered with Ag-NPs increased values of $\mathrm{LOOH}(P=0.033)$ and MDA $(P=0.005)$ in the plasma were noted. In comparison to the control, there was a decrease in 
Table 5. Measurements of the villi and crypts of the jejunum

\begin{tabular}{|c|c|c|c|c|}
\hline Indices & & $\begin{array}{l}\text { Villi of the } \\
\text { jejunum, } \\
\mu \mathrm{m}\end{array}$ & $\begin{array}{l}\text { Crypts } \\
\text { of the } \\
\text { jejunum, } \mu \mathrm{m}\end{array}$ & $\begin{array}{l}\text { Villus } \\
\text { height : crypt } \\
\text { depth ratio }\end{array}$ \\
\hline \multicolumn{5}{|l|}{ Treatment $^{1}$} \\
\hline control & & 2185 & 154.62 & 14.11 \\
\hline \multicolumn{5}{|l|}{ Ag-NP-treated } \\
\hline$S-5_{(D 1)}$ & & $2232^{*}$ & 163.4 & $13.65^{*}$ \\
\hline$S-5_{(D 2)}$ & & 2037 & 157.9 & $12.89^{*}$ \\
\hline$S-25_{(D 1)}$ & & 1982 & $184.2^{*}$ & $10.86^{*}$ \\
\hline $\mathrm{S}-25_{(\mathrm{D} 2)}$ & & $1878^{*}$ & $176.4^{*}$ & $10.64^{*}$ \\
\hline$S-40_{(D 1)}$ & & $1946^{*}$ & $184.6^{*}$ & $10.53^{*}$ \\
\hline$S-40_{(D 2)}$ & & $1831^{*}$ & $168.2^{*}$ & $10.88^{*}$ \\
\hline SEM & & 0.236 & 0.018 & 0.037 \\
\hline \multicolumn{5}{|l|}{ Main effects } \\
\hline \multirow[t]{3}{*}{ size effect (S) } & S-5 & $2134^{a}$ & $160.6^{b}$ & $13.27^{\mathrm{a}}$ \\
\hline & S-25 & $1930^{\mathrm{ab}}$ & $180.3^{a}$ & $10.75^{b}$ \\
\hline & S-40 & $1888^{b}$ & $176.4^{\mathrm{ab}}$ & $10.70^{\mathrm{b}}$ \\
\hline \multirow[t]{2}{*}{ dosage effect (D) } & D1 & 2053 & 177.4 & 11.68 \\
\hline & $\mathrm{D} 2$ & 1915 & 167.5 & 11.47 \\
\hline \multicolumn{5}{|l|}{$P$-value } \\
\hline \multicolumn{2}{|l|}{ control vs all others } & 0.006 & 0.012 & 0.021 \\
\hline \multicolumn{2}{|l|}{ S effect } & 0.042 & 0.031 & 0.032 \\
\hline \multicolumn{2}{|l|}{ D effect } & 0.164 & 0.264 & 0.365 \\
\hline \multicolumn{2}{|l|}{$S \times D$ interaction } & 0.224 & 0.342 & 0.745 \\
\hline
\end{tabular}

${ }^{1}$ see Table 2; * - means within the same column differ significantly from the control at $P \leq 0.05$ as a result of Dunnett's mean comparison; ab - means with different superscripts within the same column differ significantly $(P \leq 0.05)$ according to Newman-Keuls test (for treatments only if interaction $\mathrm{S} \times \mathrm{T}$ is significant; for main effects only if main effect ( $\mathrm{S}$ or $\mathrm{D}$ ) is significant); SEM - standard error of the mean (SD for all chickens divided by square root of number of chickens, $n=56$ )

GSH and an increase in GSSG contents $(P=0.052)$ and SOD activity $(P=0.042)$ in chickens from the S-5 $5_{(\mathrm{D} 2)}$ treatment $(P=0.027)$, while an increase in GPx activity $(P=0.024)$ was noted in $\mathrm{S}-5_{(\mathrm{D} 1)}, \mathrm{S}-5_{(\mathrm{D} 2)}$ and $\mathrm{S}-40_{(\mathrm{D} 1)}$ treatments (Table 8 ). In the breast muscle, the S-5 $5_{(\mathrm{D} 1)}$ treatment increased the content of LOOH $(P=0.003)$ and MDA $(P=0.018)$, while the S-5 $5_{(\mathrm{D} 2)}$ treatment increased only the content of LOOH $(P=0.003)$ as compared to the control (Table 9). In comparison to the control group, the $\mathrm{S}-25_{(\mathrm{D} 1)}$ treatment resulted in a decrease in MDA content $(P=0.018)$, while the $\mathrm{S}-40_{(\mathrm{D} 2)}$ treatment caused a decrease in SOD activity $(P<0.001)$ in the chicken breast muscle (Table 9).

\section{Effect of dosage of silver nanoparticles}

The chickens receiving a hydrocolloid of $\mathrm{Ag}$ nanoparticles at a concentration of $5 \mathrm{mg} \cdot 1^{-1}$ in treatment D1 ingested a dose of $2.87 \mathrm{mg}$ per bird, while in D2 they ingested a dose of $12.25 \mathrm{mg}$ per bird. Experimental treatments D1 and D2 did not affect
Table 6. Inflammation indices (erythrocyte sedimentation rate (ESR), leukocytes content (WBC), ceruloplasmin activity (Cp) and interleukin 6 level (IL-6)) of chicken blood

\begin{tabular}{|c|c|c|c|c|c|}
\hline \multicolumn{2}{|l|}{ Indices } & $\begin{array}{l}\text { ESR, } \\
\mathrm{mm} \cdot \mathrm{h}^{-1}\end{array}$ & $\begin{array}{l}\text { WBC, } \\
\left.10^{9} \cdot\right|^{-1}\end{array}$ & $\begin{array}{l}\text { Cp, } \\
\mathrm{U} \cdot \mathrm{I}^{-1}\end{array}$ & $\begin{array}{l}\mathrm{IL}-6, \\
\mathrm{pg} \cdot \mathrm{ml}^{-1}\end{array}$ \\
\hline \multicolumn{6}{|l|}{ Treatment $^{1}$} \\
\hline \multicolumn{2}{|l|}{ control } & 2.26 & 22.61 & 0.328 & 0.062 \\
\hline \multicolumn{6}{|l|}{ Ag-NP-treated } \\
\hline \multicolumn{2}{|l|}{$S-5_{(D 1)}$} & 2.35 & 23.09 & $0.267^{*}$ & $0.075^{\star}$ \\
\hline \multicolumn{2}{|l|}{$S-5_{(D 2)}$} & 2.44 & 22.64 & $0.259^{*}$ & 0.064 \\
\hline \multicolumn{2}{|l|}{$S-25_{(01)}$} & 2.17 & 23.12 & 0.308 & $0.071^{*}$ \\
\hline \multicolumn{2}{|l|}{$\mathrm{S}-25_{(\mathrm{D} 2)}$} & 2.37 & 24.26 & 0.331 & 0.058 \\
\hline \multicolumn{2}{|l|}{$\mathrm{S}-40_{(\mathrm{D} 1)}$} & 2.41 & 23.09 & 0.318 & 0.062 \\
\hline \multicolumn{2}{|l|}{$\mathrm{S}-40_{(\mathrm{D} 2)}$} & $3.11^{*}$ & 22.37 & 0.314 & $0.073^{*}$ \\
\hline \multicolumn{2}{|l|}{ SEM } & 0.022 & 0.004 & 0.011 & 0.006 \\
\hline \multicolumn{6}{|l|}{ Main effects } \\
\hline \multirow[t]{3}{*}{ size effect (S) } & S-5 & $2.39^{b}$ & 22.70 & $0.263^{b}$ & 0.069 \\
\hline & S-25 & $2.27^{b}$ & 23.69 & $0.319^{a}$ & 0.064 \\
\hline & S-40 & $2.76^{a}$ & 22.72 & $0.316^{a}$ & 0.067 \\
\hline \multirow[t]{2}{*}{ dosage effect (D) } & D1 & 2.31 & 23.10 & 0.297 & 0.069 \\
\hline & D2 & 2.64 & 23.09 & 0.301 & 0.065 \\
\hline \multicolumn{6}{|l|}{$P$-value } \\
\hline \multicolumn{2}{|c|}{ control vs all others } & 0.024 & 0.632 & 0.039 & 0.048 \\
\hline \multicolumn{2}{|l|}{ S effect } & 0.051 & 0.264 & 0.042 & 0.074 \\
\hline \multicolumn{2}{|l|}{ D effect } & 0.254 & 0.842 & 0.082 & 0.126 \\
\hline \multicolumn{2}{|l|}{$S \times D$ interaction } & 0.355 & 0.514 & 0.625 & 0.312 \\
\hline
\end{tabular}

${ }^{1}$ see Table 2; * - means within the same column differ significantly from the control at $P \leq 0.05$ as a result of Dunnett's mean comparison; ab - means with different superscripts within the same column differ significantly $(P \leq 0.05)$ according to Newman-Keuls test (for main effects only if main effect (S or D) is significant); SEM - standard error of the mean (SD for all chickens divided by square root of number of chickens, $n=56$ )

the chicken growth performance (Table 3), the length of the villi and depth of the crypts (Table 5), or indicators of systemic inflammation (Table 6). Compared to D1, D2 chickens had a higher content of Ag in the gut $(P=0.002)$ and liver $(P=0.016)$ (Table 4). Chickens from D1 and D2 treatments showed no Ag accumulation in the heart or breast muscle (Table 4). The chickens from the D2 treatment had a higher NBT value in the blood $(P=0.044)$ than D1 chickens (Table 7). In the case of NBT, the statistical interaction of dose and size of Ag-NPs $(P=0.012)$ was due to the different effects of the two doses of Ag-NPs: dose D1 decreased NBT while dose D2 - increased (Table 7). The plasma of the D2 chickens had lower content of GSH $(P=0.021)$ and higher content of GSSG $(P=0.043)$ than the chickens from the D1 treatment (Table 8$)$. Lower SOD activity $(P=0.008)$ was noted in the homogenates of the breast muscle of the D2 chickens than of the D1 chickens (Table 9). 
Table 7. Immunological indices (immunoglobulin $A$ and $Y$ content (IgA and $\lg Y$, respectively), percentage of phagocytic cells (\%PC), phagocytic index (PI), test of reduction of nitroblue-tetrazolium by heterophils (NBT) and lysozyme content) of chicken blood

\begin{tabular}{|c|c|c|c|c|c|c|c|}
\hline \multirow{2}{*}{\multicolumn{2}{|c|}{ Indices }} & $\lg A$ & $\lg Y$ & \multirow[b]{2}{*}{$\% \mathrm{PC}$} & \multirow[b]{2}{*}{$\mathrm{Pl}$} & \multirow{2}{*}{$\begin{array}{l}\text { NBT } \\
\text { test }\end{array}$} & \multirow{2}{*}{$\begin{array}{l}\text { Lyso- } \\
\text { zyme, } \\
\mathrm{mg} \cdot \mathrm{l}^{-1}\end{array}$} \\
\hline & & \multicolumn{2}{|c|}{$\mathrm{ng} \cdot \mathrm{ml}^{-1}$} & & & & \\
\hline \multicolumn{8}{|l|}{ Treatment $^{1}$} \\
\hline control & & 0.206 & 0.694 & 35.49 & 5.11 & 29.83 & 3.97 \\
\hline \multicolumn{8}{|c|}{ Ag-NP-treated } \\
\hline S-5 $5_{(D 1)}$ & & 0.189 & 0.648 & 38.28 & 4.87 & $32.14^{b}$ & $5.45^{*}$ \\
\hline$S-5_{(D 2)}$ & & 0.194 & 0.709 & 34.46 & 5.06 & $36.42^{\mathrm{a}^{*}}$ & $5.69^{*}$ \\
\hline S-25(D1) & & 0.201 & 0.719 & 39.14 & 4.88 & $30.61^{b}$ & $5.28^{*}$ \\
\hline S-25 (D2) & & 0.215 & 0.675 & 33.67 & 5.24 & $37.88^{a^{\star}}$ & 4.09 \\
\hline$S-40_{(D 1)}$ & & 0.193 & 0.683 & 37.48 & 5.13 & $34.25^{\mathrm{ab}}$ & 4.17 \\
\hline$S-40_{(D 2)}$ & & 0.206 & 0.713 & 35.44 & 4.63 & $38.44^{\mathrm{a}^{\star}}$ & $4.86^{*}$ \\
\hline SEM & & 0.057 & 0.091 & 0.008 & 0.012 & 0.064 & 0.043 \\
\hline \multicolumn{8}{|l|}{ Main effects } \\
\hline \multirow{3}{*}{$\begin{array}{l}\text { size } \\
\text { effect (S) }\end{array}$} & S-5 & 0.191 & 0.678 & 36.37 & 4.96 & 34.28 & $5.57^{\mathrm{a}}$ \\
\hline & S-25 & 0.208 & 0.697 & 36.40 & 5.06 & 34.24 & $4.68^{b}$ \\
\hline & S-40 & 0.199 & 0.698 & 36.48 & 4.88 & 36.34 & $4.51^{b}$ \\
\hline \multirow{2}{*}{$\begin{array}{l}\text { dosage } \\
\text { effect (D) }\end{array}$} & D1 & 0.194 & 0.683 & 38.30 & 4.96 & $32.33^{B}$ & 4.96 \\
\hline & D2 & 0.205 & 0.699 & 34.52 & 4.97 & $37.58^{\mathrm{A}}$ & 4.88 \\
\hline \multicolumn{8}{|l|}{$P$-value } \\
\hline \multicolumn{2}{|c|}{$\begin{array}{l}\text { control } \\
\text { vs all others }\end{array}$} & 0.092 & 0.354 & 0.609 & 0.824 & 0.042 & 0.022 \\
\hline \multicolumn{2}{|l|}{ S effect } & 0.073 & 0.118 & 0.088 & 0.108 & 0.071 & 0.034 \\
\hline \multicolumn{2}{|l|}{ D effect } & 0.062 & 0.093 & 0.063 & 0.912 & 0.044 & 0.077 \\
\hline \multicolumn{2}{|c|}{$S \times D$ interaction } & 0.074 & 0.071 & 0.236 & 0.064 & 0.012 & 0.109 \\
\hline
\end{tabular}

${ }^{1}$ see Table 2; ${ }^{*}$ - means within the same column differ significantly from the control at $P \leq 0.05$ as a result of Dunnett's mean comparison; ${ }^{a-b}$ or ${ }^{A-B}$ - means within the same column with different superscripts differ significantly $(P \leq 0.05)$ according to Newman-Keuls test (for treatments only if interaction $S \times T$ is significant; for main effects only if main effect ( $S$ or D) is significant); SEM - standard error of the mean (SD for all chickens divided by square root of number of chickens, $n=56$ )

\section{Effect of silver nanoparticle size}

Increasing size of $\mathrm{Ag}$ nanoparticles in the hydrocolloid administered per os to chickens was not found to affect production results (Table 3). As the Ag-NP size increased in the hydrocolloid, accumulation of silver increased in the intestine $(P=0.014)$ and decreased in the liver $(P=0.001)$. In addition, a statistical interaction of dose and nanoparticle size was noted for $\mathrm{Ag}$ content in the intestine and liver; dose D2 increased and dose D1 decreased silver content in the intestine $(P=0.036)$ and liver $(P=0.042)$ (Table 4$)$. Increasing size of Ag-NPs in the hydrocolloid of Ag nanoparticles led to a decrease in the length of the villi $(P=0.042)$ and an increase in the crypt depth $(P=0.031)$ in the small intestine of the chickens. This effect was reflected in villus length:crypt depth ratio $(P=0.032)$
Table 8. Antioxidant indices (content of lipid peroxides ( $\mathrm{LOOH}$ ), malondialdehyde (MDA), reduced glutathione (GSH) and oxidized glutathione (GSSG), and activity of superoxide dismutase (SOD), glutathione peroxidase (GPx) and catalase (CAT)) of chicken blood

\begin{tabular}{|c|c|c|c|c|c|c|c|}
\hline \multirow{2}{*}{ Indices } & \multicolumn{2}{|c|}{$\mathrm{LOOH} \mathrm{MDA}$} & GSH & GSSG & SOD & GPx & CAT \\
\hline & \multicolumn{4}{|c|}{$\mu \mathrm{mol} \cdot \mathrm{I}^{-1}$} & \multicolumn{3}{|c|}{$\mathrm{U} \cdot \mathrm{g}^{-1} \mathrm{Hb}$} \\
\hline \multicolumn{8}{|l|}{ Treatment $^{1}$} \\
\hline control & 7.26 & 0.829 & 0.334 & 0.042 & 142.2 & 88.64 & 612.5 \\
\hline \multicolumn{8}{|c|}{ Ag-NP-treated } \\
\hline$S-5_{(D 1)}$ & $8.54^{*}$ & $1.088^{*}$ & 0.396 & 0.045 & 138.6 & $95.36^{*}$ & 582.3 \\
\hline$S-5_{(D 2)}$ & $9.32^{*}$ & $1.106^{*}$ & $0.133^{*}$ & $0.053^{*}$ & $156.3^{*}$ & $106.2^{*}$ & 623.4 \\
\hline$S-25_{(D 1)}$ & $8.96^{*}$ & $1.046^{*}$ & $0.464^{*}$ & 0.041 & 148.4 & 84.67 & 588.6 \\
\hline$S-25_{(D 2)}$ & $8.67^{*}$ & 0.887 & 0.342 & 0.046 & 151.5 & 79.94 & 614.2 \\
\hline$S-40_{(D 1)}$ & 7.88 & 0.874 & 0.329 & 0.044 & 145.3 & $94.66^{*}$ & 586.9 \\
\hline$S-40_{(D 2)}$ & $8.86^{*}$ & $0.976^{*}$ & 0.395 & $0.055^{*}$ & 143.1 & $111.3^{*}$ & 608.6 \\
\hline SEM & 0.039 & 0.145 & 0.088 & 0.026 & 0.036 & 0.055 & 0.034 \\
\hline
\end{tabular}

Main effects

$\begin{array}{lllllllll}\begin{array}{l}\text { size } \\ \text { effect (S) }\end{array} & \text { S-5 } & 8.93 & 1.097 & 0.264^{\mathrm{b}} & 0.049 & 147.4 & 100.7^{\mathrm{a}} & 602.8 \\ & \text { S-25 } & 8.81 & 0.966 & 0.403^{\mathrm{a}} & 0.043 & 149.9 & 82.30^{\mathrm{b}} & 601.4 \\ & \text { S-40 } & 8.37 & 0.925 & 0.362^{\mathrm{ab}} & 0.042 & 144.2 & 102.9^{\mathrm{a}} & 597.7 \\ \begin{array}{l}\text { dosage } \\ \text { effect (D) }\end{array} & \text { D1 } & 8.46 & 1.002 & 0.396^{\mathrm{A}} & 0.043^{\mathrm{B}} & 144.1 & 91.56 & 585.9 \\ \begin{array}{l}P \text {-value } \\ \text { control }\end{array} & 8.95 & 0.989 & 0.290^{\mathrm{B}} & 0.051^{\mathrm{A}} & 150.3 & 99.14 & 615.4 \\ \begin{array}{l}\text { vs all others } \\ \text { S effect }\end{array} & 0.033 & 0.005 & 0.027 & 0.052 & 0.042 & 0.014 & 0.061 \\ \begin{array}{l}\text { D effect } \\ \text { S } \times \text { D interaction }\end{array} & 0.0712 & 0.067 & 0.062 & 0.036 & 0.708 & 0.079 & 0.051 & 0.064 \\ \end{array}$

${ }^{1}$ see Table 2; * - means within the same column differ significantly from the control at $P \leq 0.05$ as a result of Dunnett's mean comparison; ${ }^{a-b}$ or ${ }^{A-B}$ - means within the same column with different superscripts differ significantly $(P \leq 0.05)$ according to Newman-Keuls test (for main effects only if main effect ( $S$ or $D$ ) is significant); SEM - standard error of the mean (SD for all chickens divided by square root of number of chickens, $n=56$ )

(Table 5). The increase in a size of the Ag-NPs in the hydrocolloid resulted in an increase in ESR $(P=0.051)$ in the blood of the chickens (Table 6). In treatments $\mathrm{S}-25$ and $\mathrm{S}-40$, the Cp activity in the blood was higher than in S-5 $(P=0.042)$, but at the control level. The content of lysozyme in the blood was lower in the S-25 and S-40 groups than in $\mathrm{S}-5$, but it was still higher than in the control $(P=0.034)$ (Table 7). In the blood of S-25 chickens GSH content $(P=0.036)$ and GPx activity $(P=0.051)$ were higher than in chickens from S-5 and S-40 treatments (Table 8$)$. In the S-25 chickens, a lower MDA level $(P=0.047)$ in the breast muscle was noted as well (Table 9). As compared to S-5 and S-25 treatments, lower SOD activity was observed in the breast muscle of the S-40 chickens (Table 9). 
Table 9. Antioxidant indices (content of lipid peroxides ( $\mathrm{LOOH}$ ), malondialdehyde (MDA), reduced glutathione (GSH) and oxidized glutathione (GSSG), and activity of superoxide dismutase (SOD) and catalase (CAT)) of the breast muscle of the chickens

\begin{tabular}{|c|c|c|c|c|c|c|c|}
\hline \multirow{2}{*}{\multicolumn{2}{|c|}{ Indices }} & $\mathrm{LOOH}$ & MDA & GSH & GSSG & SOD & CAT \\
\hline & & \multicolumn{4}{|c|}{$\mu \mathrm{mol} \cdot \mathrm{g}^{-1}$} & \multicolumn{2}{|c|}{$\mathrm{U} \cdot \mathrm{g}^{-1}$ protein } \\
\hline \multicolumn{8}{|l|}{ Treatments } \\
\hline control & & 2.856 & 0.496 & 4.265 & 0.233 & 5.236 & 12.85 \\
\hline \multicolumn{8}{|c|}{ Ag-NP-treated } \\
\hline$S-5_{(D 1)}$ & & $3.054^{*}$ & $0.533^{*}$ & 4.125 & 0.245 & 4.944 & 13.12 \\
\hline$S-5_{(D 2)}$ & & $3.025^{\star}$ & 0.506 & 4.165 & 0.264 & 5.136 & 12.77 \\
\hline$S-25_{(D 1)}$ & & 2.941 & $0.388^{*}$ & $4.058^{*}$ & 0.255 & 5.106 & 11.89 \\
\hline $\mathrm{S}-25_{(\mathrm{D} 2)}$ & & 2.861 & 0.482 & 4.235 & 0.208 & 5.078 & 12.35 \\
\hline$S-40_{(D 1)}$ & & 2.749 & 0.514 & $4.095^{\star}$ & 0.274 & 5.366 & 11.52 \\
\hline $\mathrm{S}-40_{(\mathrm{D} 2)}$ & & 2.944 & 0.503 & 4.147 & 0.247 & $2.145^{*}$ & 12.39 \\
\hline SEM & & 0.207 & 0.049 & 0.095 & 0.007 & 0.167 & 0.103 \\
\hline \multicolumn{8}{|l|}{ Main effects } \\
\hline \multirow{3}{*}{$\begin{array}{l}\text { size } \\
\text { effect (S) }\end{array}$} & S-5 & 3.039 & $0.519^{a}$ & 4.145 & 0.254 & $5.040^{\mathrm{a}}$ & 12.94 \\
\hline & S-25 & 2.901 & $0.435^{b}$ & 4.146 & 0.231 & $5.090^{\mathrm{a}}$ & 12.12 \\
\hline & $S-40$ & 2.846 & $0.508^{\mathrm{ab}}$ & 4.121 & 0.260 & $3.755^{\mathrm{b}}$ & 11.95 \\
\hline \multirow{2}{*}{$\begin{array}{l}\text { dosage } \\
\text { effect (D) }\end{array}$} & D1 & 2.914 & 0.478 & 4.092 & 0.258 & $5.138^{A}$ & 12.17 \\
\hline & D2 & 2.943 & 0.497 & 4.182 & 0.239 & $4.119^{B}$ & 12.50 \\
\hline \multicolumn{8}{|l|}{$P$-value } \\
\hline \multicolumn{2}{|c|}{$\begin{array}{l}\text { control vs all } \\
\text { others }\end{array}$} & 0.003 & 0.018 & 0.046 & 0.328 & $<0.001$ & 0.109 \\
\hline \multicolumn{2}{|l|}{ S effect } & 0.063 & 0.045 & 0.071 & 0.066 & 0.002 & 0.073 \\
\hline \multicolumn{2}{|l|}{ D effect } & 0.076 & 0.133 & 0.061 & 0.073 & 0.008 & 0.084 \\
\hline \multicolumn{2}{|c|}{$S \times D$ interaction } & $n 0.067$ & 0.079 & 0.464 & 0.309 & 0.166 & 0.095 \\
\hline
\end{tabular}

${ }^{1}$ see Table 2; * - means within the same column differ significantly from the control at $P \leq 0.05$ as a result of Dunnett's mean comparison; ${ }^{a-b}$ or ${ }^{A-B}$ - means within the same column with different superscripts differ significantly $(P \leq 0.05)$ according to Newman-Keuls test (for main effects only if main effect ( $S$ or $D$ ) is significant); SEM - standard error of the mean (SD for all chickens divided by square root of number of chickens, $n=56$ )

\section{Discussion}

Ag-NPs are absorbed mainly in jejunum into enterocytes by means of active transport involving proteins, endocytosis and diffusion. In the bloodstream, Ag-NPs are bound with albumins and metallothioneins, due to their high affinity for sulfhydryl groups (-SH) (McShan et al., 2014).

According to van der Zande et al. (2012), who investigated the distribution and elimination of silver ions (in doses up to $9 \mathrm{mg} \cdot \mathrm{kg}^{-1} \mathrm{BW}$ ) and $\mathrm{Ag}$-NPs (in doses up to $90 \mathrm{mg} \cdot \mathrm{kg}^{-1} \mathrm{BW}$ ) in rats, $\mathrm{Ag}$ was detected in blood, liver, kidney, brain, spleen, testis, lung, heart and bladder. In all silver treatments the highest levels of Ag were observed in liver and spleen. Silver concentrations in the tested organs were highly correlated with the amount of silver ions in the AgNPs suspensions. Nanoparticles have high potential to aggregate or agglomerate in solution. Gliga et al. (2014) showed that the primary particle size seems to be more important than the size of the agglomerates for silver release and for toxicity as well. In the present study, irrespective of the dose or size of Ag-NPs, Ag was found to accumulate in the wall of the small intestine and in the liver of the chickens, but not in the heart or breast muscle. In our study it was shown that ingestion of $12.25 \mathrm{mg} \mathrm{Ag-NPs}$ per bird led to greater accumulation of silver in the small intestinal wall and the liver than in the case of $2.87 \mathrm{mg} \mathrm{Ag-NPs}$ per bird. It was also found that as the size of Ag-NPs in the hydrocolloid increased, accumulation of this metal increased in the enterocytes of the small intestine but decreased in the hepatocytes. Smaller nanoparticles $(5 \mathrm{~nm})$ more easily penetrated the bloodstream through the enterocytes than larger ones ( 25 or $40 \mathrm{~nm}$ ), and then were accumulated to a greater degree in hepatocytes. In the research on chickens it was shown that administration of nanosilver leads to accumulation of this metal in the intestinal walls (Ognik et al., 2017). It was noted that transepithelial transport occurs with a similar efficiency for Ag-NPs as for silver ions and that silver is well absorbed (EFSA, 2016). This is in the agreement with a report by the Danish Environmental Protection Agency (Binderup et al., 2013) on the systemic absorption of ingested nanomaterials. In this report it was noted that Ag-NPs dissolve in the gastrointestinal tract prior to absorption into the bloodstream, and subsequently reach primarily the liver and spleen and to a lesser degree other organs.

In our study, ingestion by chickens of a hydrocolloid of Ag-NPs $5 \mathrm{~nm}$ in size at a dosage of $2.87 \mathrm{mg}$ per bird increased the length of the villi in the small intestine. Administration of a hydrocolloid of Ag-NPs $5 \mathrm{~nm}$ in size at a dosage of $12.25 \mathrm{mg}$ per bird had no effect on the histology of the small intestine. However, administration of Ag-NPs of larger size -25 and $40 \mathrm{~nm}$ - in the hydrocolloid, even at the lower dose ( $2.87 \mathrm{mg}$ per bird), caused a decrease in villus length and an increase in crypt depth in the small intestine of the chickens. The increase in villus length may have resulted from greater accumulation of larger Ag-NPs. This is probably due to the formation of bonds between $\mathrm{Ag}$ and proteins of enterocytes. So, the efficiency of Ag retention in the intestinal walls is nanoparticles size- and dosedependent. In the study of Jeong et al. (2010) the presence of Ag-NPs in the small and large intestines of rats exposed to Ag-NPs $(60 \mathrm{~nm})$ for 28 days was observed. Also, in that study the deposition of $\mathrm{Ag}$-NPs in the intestines was dose-dependent (the 
higher doses, the greater accumulation of the element). According to Shahare et al. (2013) damage of the intestinal epithelium was found in mice, to which Ag-NPs were administrated orally at a dose of $10 \mathrm{mg} \cdot \mathrm{kg}^{-1} \mathrm{BW} \cdot \mathrm{d}^{-1}$ for 21 days. The authors assumed that the decreased length of the microvilli reduced the absorptive capacity of the intestinal epithelium and led to a reduction of body weight. In our previous experiment on chickens receiving an aqueous solution of Ag-NPs $\left(5 \mathrm{mg} \cdot \mathrm{kg}^{-1} \mathrm{BW} \cdot \mathrm{d}^{-1}\right)$ with a lipid coating, increased villus length and crypt depth were observed, whereas in chickens receiving Ag-NPs without the lipid coating a decrease in villus length and an increase in crypt depth was found (Ognik et al., 2016a). In the study of Sawosz et al. (2007) it was shown that administration of a solution of Ag-NPs to quails in drinking water exerted no destructive effect on the intestinal villi. Also in this study it stated that nanosilver can affect the first, outer layer of intestinal wall cells and induce their exfoliation, but without the damage of the tissue itself.

Ag-NPs have the ability to interact with components of non-specific immunity, both humoral and cellular. Within the first few seconds after contact with body fluids, metallic nanoparticles form a protein corona composed of fibrinogen, immunoglobulins, albumins and complement proteins, although lysozyme and acute phase proteins may also undergo this process. This phenomenon stimulates complement, promotes phagocytosis of the particles and initiates the inflammatory process, while at the same time induces a change in the spatial conformation of proteins, which may lead to a loss of their biological activity (Javanović and Palić, 2012). It was shown in this study that the administration of a hydrocolloid of $5 \mathrm{~nm} \mathrm{Ag-NPs} \mathrm{to} \mathrm{chickens} \mathrm{at} \mathrm{both}$ doses, 2.87 and $12.25 \mathrm{mg}$ per bird reduced $\mathrm{Cp}$ activity in the plasma. In the S-5 $5_{(\mathrm{D} 1)}$ and $\mathrm{S}-5_{(\mathrm{D} 2)}$ treatments also the accumulation of NPs in liver was the highest, so it may be assumed that there might have occurred some liver dysfunctions resulting in a decrease in $\mathrm{Cp}$ activity in these treatments. Administration of Ag-NPs, with larger sizes (25 and $40 \mathrm{~nm}$ ), did not affect $\mathrm{Cp}$ activity. The increase in IL-6, lysozyme and NBT levels observed in our research may indicate the stimulation of the immune system of chickens receiving Ag-NPs, even at small size $(5 \mathrm{~nm})$ and dose. In the present study it was also found that increasing the size of Ag-NPs administered to the chickens to $40 \mathrm{~nm}$ increased the ESR value. A particularly high value for this indicator as compared to the control was noted in the blood of the chickens receiving $40 \mathrm{~nm}$ Ag-NPs at a dose of $12.25 \mathrm{mg}$ per bird. It can be assumed that the larger nanoparticles, which accumulation was the greatest in intestinal cells, in addition to their adverse effect on the growth of villi and crypts, also induced inflammatory reactions. During the inflammatory reaction, there is an increase in the concentration of pro-inflammatory cytokines, which task is to restore systemic homeostasis (Polińska et al., 2009). Changes in the relative proportions of individual serum proteins during inflammation (an increase in globulins and fibrinogen and a decrease in albumin) result in faster sedimentation of blood cells. In the present study, irrespective of the size of the Ag-NPs in the hydrocolloid, administration of the higher dose of $12.25 \mathrm{mg}$ per bird was found to increase the NBT value in the chicken blood. Decreasing the size of Ag-NPs in the hydrocolloid administered to the chickens caused an increase in lysozyme content in the blood. The increase in the number of NBT-reducing cells may be indicative of the stimulatory effect of administration of Ag-NPs on heterophils and of increased capacity of heterophils for respiratory burst and production of superoxide radicals. Once ingested by neutrophils, nanoparticles (NPs) are enclosed in phagosomes and chronically stimulate them to respiratory burst, leading to their NETosis. As a result, nanoparticles are released and become available to other phagocytes, enabling long-term recirculation in the body. NETosis induced by NPs probably leads to the death of many mature forms of neutrophils, and new immature cells may not be fully competent (Javanović and Palić, 2012). During the formation of the heterophil extracellular trap, degranulation of granulocytes and monocytes and the release of enzymes present in them, including lysozyme, may also occur. Nanosilver administered per os to chickens (both $22 \mathrm{~nm} \mathrm{Ag-nano} \mathrm{and} 5 \mathrm{~nm}$ AgL-nano - Ag-NPs in lipid capsules) has been shown to stimulate phagocytosis and increase the metabolic activity of leukocytes (Ognik et al., 2016b).

In our research it was shown that irrespective of the dosage and size of Ag-NPs, with the exception of the $\mathrm{S}-40_{(\mathrm{D} 1)}$ treatment, administration of Ag-NPs to chickens increased plasma levels of $\mathrm{LOOH}$ and MDA. However, increasing the dosage of Ag-NPs for chickens intensified oxidative reactions in the body. This is evidenced by the fact that the plasma content of GSH was lower and that of GSSG was higher in the chickens treated with Ag-NPs at $12.25 \mathrm{mg}$ per bird as compared to the chickens receiving a dose of $2.87 \mathrm{mg}$ per bird. Moreover, the breast muscle of chickens receiving Ag-NPs at a dose of $12.25 \mathrm{mg}$ 
per bird showed lower SOD activity than in chickens receiving a dose of $2.87 \mathrm{mg}$ per bird. Evidence that the Ag-NPs $\left(5 \mathrm{mg} \cdot \mathrm{kg}^{-1} \mathrm{BW} \cdot \mathrm{d}^{-1}\right)$ in the experiment initiated oxidative stress in the organism of the chickens is the increase in $\mathrm{LOOH}$ and MDA contents, and decrease in SOD and CAT activities noted in the plasma (Ognik et al., 2016b). Ahmadi (2012), after administering nanosilver to chickens in concentrations of 20, 40 and $60 \mathrm{ppm} \cdot \mathrm{kg}^{-1}$ of feed, also observed an increase in the content of MDA and a decrease in the activity of antioxidant enzymes (SOD, GPx and CAT) in the plasma, which was in direct proportion to the dose of nanosilver in the feed. In our study it was noted that from three sizes of AgNPs $(5,25$ and $40 \mathrm{~nm})$ administered to chickens in a hydrocolloid, the $25 \mathrm{~nm} \mathrm{Ag-NPs} \mathrm{showed} \mathrm{the} \mathrm{least}$ tendency to induce oxidative reactions. This is confirmed by the lowest MDA content in the breast muscle and the highest GSH content in blood of chickens receiving $25 \mathrm{~nm} \mathrm{Ag-NPs}$ in a dose of $2.87 \mathrm{mg}$ per bird compared to control. Moreover the GPx activity in the erythrocytes was the lowest in S-25 treatment in comparison to S-5 and S-40 ones, but at the control level. Normally, as the size decreases, the bioavailability of Ag-NPs becomes higher. Liu et al. (2010) compared the toxicities of three kinds of nanosilver at different sizes $(5,20$, and $50 \mathrm{~nm})$, and showed that smaller nanoparticles enter cells more easily than larger ones, which may be the cause of greater toxic effects. The particles with larger sizes may be cleared more easily than the smaller ones (Wen et al. 2016).

\section{Conclusions}

It has been demonstrated that oral administration of silver nanoparticles (Ag-NPs) to chickens influences the morphology and functioning of the gastrointestinal tract, as well as the parameters of immune and redox status. This effect varies depending on the dose and size of the used Ag-NPs, so there is a need for further investigation in order to assess the suitability of Ag-NPs in poultry nutrition.

\section{References}

Aebi H., 1984. Catalase in vitro. Methods Enzymol. 105, 121-126, https://doi.org/10.1016/S0076-6879(84)05016-3

Ahmadi F., 2012. Impact of different levels of silver nanoparticles (AgNPs) on performance, oxidative enzymes and blood parameters in broiler chicks. Pak. Vet. J. 32, 325-328

AshaRani P.V., Low Kah Mun G., Hande M.P., Valiyaveettil S., 2009. Cytotoxicity and genotoxicity of silver nanoparticles in human cells. ACS Nano 3, 279-290, https://doi.org/10.1021/ nn800596w
Binderup M.-L., Bredsdorff L., Beltoft V.M., Mortensen A., Löschner K., Löschner K., Larsen E.H., Eriksen F.D., 2013. Systemic absorption of nanomaterials by oral exposure. Part of the "Better control of nano" initiative 2012-2015. Danish Environmental Protection Agency. Copenhagen (Denmark), http:// orbit.dtu.dk/files/59606121/Systemic\%20absorption $\% 20$ of $\% 20$ nanomaterials $\% 20$ by $\% 20$ oral\%20 exposure $\% 20978$ 87-93026-51-3.pdf (accessed on 18.01.2018)

Bomski H., 1995. Biernacki's reaction. In: H. Bomski. Basic Hematology Laboratory Analyses (in Polish). National Institute of Medical Publications, Warsaw (Poland), pp. 161-168

Carlson C., Hussain S.M., Schrand A.M., Braydich-Stolle L.K., Hess K.L., Jones R.L., Schlager J.J., 2008. Unique cellular interaction of silver nanoparticles: size-dependent generation of reactive oxygen species. J. Phys. Chem. B 112, 1360813619, https://doi.org/10.1021/jp712087m

EFSA Panel on Food Additives and Nutrient Sources added to Food, 2016. Scientific opinion on the re-evaluation of silver (E 174) as food additive. EFSA J. 14, 4364, https://doi.org/10.2903/j. efsa.2016.4364.

Gliga A.R., Skoglund S., Wallinder I.O., Fadeel B., Karlsson H.L., 2014. Size-dependent cytotoxicity of silver nanoparticles in human lung cells: the role of cellular uptake, agglomeration and $\mathrm{Ag}$ release. Part. Fibre Toxicol. 11, https://doi.org/10.1186/17438977-11-11

Gordon O., Vig Slenters T., Brunetto P.S., VillaruzA.E., Sturdevant D.E., Otto M., Landmann R., Fromm K.M., 2010. Silver coordination polymers for prevention of implant infection: thiol interaction, impact on respiratory chain enzymes, and hydroxyl radical induction. Antimicrob. Agents Chemother. 54, 4208-4218, https://doi.org/10.1128/AAC.01830-09

Javanović B., Palić D., 2012. Immunotoxicology of non-functionalized engineered nanoparticles in aquatic organisms with special emphasis on fish - review of current knowledge, gap identification, and call for further research. Aquat. Toxicol. 118-119, 141-151, https://doi.org/10.1016/j.aquatox.2012.04.005

Jeong G.N., Jo U.B., Ryu H.Y., Kim Y.S., Song K.S., Yu I.J., 2010. Histochemical study of intestinal mucins after administration of silver nanoparticles in Sprague-Dawley rats. Arch. Toxicol. 84, 63-69, https://doi.org/10.1007/s00204-009-0469-0

Kulak E., Ognik K., Stępniowska A., Drażbo A., 2018a. Effect of nanoparticles silver on redox status and accumulation $\mathrm{Ag}$ in tissues chicken. J. Sci. Food Agric. https://doi.org/10.1002/ jsfa. 8925

Kulak E., Sembratowicz I., Stępniowska A., Ognik K., 2018b. The effect of administration of silver nanoparticles on the immune status of chickens. Ann. Anim. Sci. https://doi.org/10.1515/ aoas-2017-0043

Liu W., Wu Y., Wang C., Li H.C., Wang T., Liao C.Y., Cui L., Zhou Q.F., Yan B., Jiang G.B., 2010. Impact of silver nanoparticles on human cells: effect of particle size. Nanotoxicology 4, 319-330, https://doi.org/10.3109/17435390.2010.483745

Małaczewska J., 2014. Impact of noble metal nanoparticles on the immune system of animals (in Polish). Med. Weter. 70, 204-208

McShan D., Ray P.C., Yu H., 2014. Molecular toxicity mechanism of nanosilver. J. Food Drug Anal. 22, 116-127, https://doi. org/10.1016/j.jfda.2014.01.010

Ognik K., Cholewińska E., Czech A., Kozłowski K., Wlazło Ł., Nowakowicz-Dębek B., Szlązak R., Tutaj K., 2016b. Effect of silver nanoparticles on the immune, redox, and lipid status of chicken blood. Czech J. Anim. Sci. 61, 450-461, https://doi. org/10.17221/80/2015-CJAS 
Ognik K., Sembratowicz I., Cholewińska E., Wlazło Ł., NowakowiczDębek B., Szlazak R., Tutaj K., 2016a. The effect of chemically-synthesized silver nanoparticles on performance and the histology and microbiological profile of the jejunum in chickens. Ann. Anim. Sci. 16, 439-450, https://doi.org/10.1515/ aoas-2015-0067

Ognik K., Stępniowska A., Kozłowski K., 2017. The effect of administration of silver nanoparticles to broiler chickens on estimated intestinal absorption of iron, calcium, and potassium. Livest. Sci. 200, 40-45, https://doi.org/10.1016/j.livsci.2017.04.002

Ognik K., Wertelecki T., 2012. Effect of different vitamin E sources and levels on selected oxidative status indices in blood and tissues as well as on rearing performance of slaughter turkey hens. J. Appl. Poult. Res. 21, 259-271, https://doi. org/10.3382/japr.2011-00366

Panyala N.R., Peña-Méndez E.M., Havel J., 2008. Silver or silver nanoparticles: a hazardous threat to the environment and human health? J. Appl. Biomed. 6, 117-129

Park B.H., Fikrig S.M., Smithwick E.M., 1968. Infection and nitroblue-tetrazolium reduction by neutrophils: a diagnostic aid. Lancet 292, 532-534, https://doi.org/10.1016/S01406736(68)92406-9

Polińska B., Matowicka-Karna J., Kemona H., 2009. The cytokines in inflammatory bowel disease (in Polish). Postepy Hig. Med. Dosw. 63, 389-394

Reidy B., Haase A., Luch A., Dawson K.A., Lynch I., 2013. Mechanisms of silver nanoparticle release, transformation and toxicity: a critical review of current knowledge and recommendations for future studies and applications. Materials 6, 2295-2350, https://doi.org/10.3390/ma6062295

Sawosz E., Binek M., Grodzik M., Zielińska M., Sysa P., Szmidt M., Niemiec T., Chwalibog A., 2007. Influence of hydrocolloidal silver nanoparticles on gastrointestinal microflora and morphology of enterocytes of quails. Arch. Anim. Nutr. 61, 444-451, https://doi.org/10.1080/17450390701664314

Shahare B., Yashpal M., Gajendra, 2013. Toxic effects of repeated oral exposure of silver nanoparticles on small intestine mucosa of mice. Toxicol. Mech. Methods 23, 161-167, https://doi.org/10 $.3109 / 15376516.2013 .764950$
Siwicki A.K., Anderson D.P., 1993. Nonspecific defence mechanisms assay in fish. II. Potential killing activity of neutrophils and macrophages, lysozyme activity in serum and organs, and total immunoglobulin $(\mathrm{Ig})$ level in serum. In: A.K. Siwicki, D.P. Anderson, J. Waluga (Ediors). Fish Diseases Diagnosis and Prevention Methods. Inland Fisheries Institute. Olsztyn (Poland), pp. 105-111

Siwicki A.K., Anderson D.P., Rumsey G.L., 1994. Dietary intake of immunostimulants by rainbow trout affects non-specific immunity and protection against furunculosis. Vet. Immunol. Immunopathol. 41, 125-139, https://doi.org/10.1016/01652427(94)90062-0

Smulikowska S., Rutkowski A. (Editors), 2005. Recommended Allowances and Nutritive Value of Feedstuffs. Poultry Feeding Standards (in Polish). $4^{\text {th }}$ Edition. The Kielanowski Institute of Animal Physiology and Nutrition, PAS, Jabłonna (Poland)

Sunderman F.W. Jr., Nomoto S., 1970. Measurement of human serum ceruloplasmin by its $p$-phenylenediamine oxidase activity. Clin. Chem. 16, 903-910

van der Zande M., Vandebriel R.J., Van Doren E. et al., 2012. Distribution, elimination, and toxicity of silver nanoparticles and silver ions in rats after 28-day oral exposure. ACS Nano 6, 7427-7442, https://doi.org/10.1021/nn302649p

Wang Z., Xia T., Liu S., 2015. Mechanisms of nanosilver-induced toxicological effects: more attention should be paid to its sublethal effects. Nanoscale 7, 7470-7481, https://doi.org/10.1039/ C5NR01133G

Wen R., Hu L., Qu G., Zhou Q., Jiang G., 2016. Exposure, tissue biodistribution, and biotransformation of nanosilver. Nanolmpact 2, 18-28, https://doi.org/10.1016/j.impact.2016.06.001

Xu Y., Tang H., Liu J.-h., Wang H., Liu Y., 2013. Evaluation of the adjuvant effect of silver nanoparticles both in vitro and in vivo. Toxicol. Lett. 219, 42-48, https://doi.org/10.1016/j. toxlet.2013.02.010

Yen H.-J., Hsu S.-h., Tsai C.-L., 2009. Cytotoxicity and immunological response of gold and silver nanoparticles of different size. Small 5, 1553-1561, https://doi.org/10.1002/smll.200900126 